\title{
Analysis of Factors That Inhibition of Intention to Quit Smokingamong Outpatients Visiting Pulmonology Clinic at Dr. Zainoel Abidin Hospitals in Banda Aceh
}

\author{
${ }^{1}$ Ferlis, ${ }^{2}$ Vera Nazhira Arifin, ${ }^{3}$ Teuku Tahlil, ${ }^{4}$ Riza Septiani, ${ }^{5}$ Surna Lastri, ${ }^{6}$ Muhammad \\ ${ }_{\mathbf{1 , 2 , 4 , 5 , 6}}$ Faculty of Public Health, Muhammadiyah University of Aceh, Banda Aceh, Indonesia \\ Muhammadiyah 91 St, Banda Aceh, Aceh, 23245 \\ ${ }^{3}$ Faculty of Nursing, Syiah Kuala University, Banda Aceh, Indonesia \\ T. Nyak Arief Darussalam St, Banda Aceh, Aceh, 23111 \\ E-mail: veraeyabogor@gmail.com
}

\begin{abstract}
Mortality rates in Indonesia are considered high with one of the contributing factors related to this condition is due to smoking behavior that is quite popular within society. Particularly, Aceh is one of the provinces with a high smoking prevalence as well as a high number of smokers. This study aimed to determine the factors that inhibit smoking cessation among outpatients who visit the pulmonology clinic at Dr. Zainoel Abidin Hospital in Banda Aceh. This study uses quantitative methods with a cross-sectional design. The population of this study is all patients who visit the pulmonology clinic at Dr. Zainoel Abidin Hospital in Banda Aceh, who are active smokers. The total sample is 65 respondents selected using the accidental sampling method. The results of the univariate analysis show that $56.92 \%$ of patients had the intention to stop smoking, $83.08 \%$ are active smokers for more than 5 years, $72.31 \%$ states about well the availability of cigarettes, $56.92 \%$ had low knowledge, $67.69 \%$ of patients had a negative attitude towards smoking cessation, $61.54 \%$ experiencing severe addiction in smoking, $70.77 \%$ smoking due to the influence of social environment. Bivariate analysis shows that there is a relationship between duration of smoking (p-value 0.029), smoking availability $(p$-value $=0.036)$, knowledge $(p$-value $=0.01)$, attitude $(p$-value $=0.03)$, cigarette addiction $(p$-value $=0,001)$, social environment ( $p$-value $=0,004)$, family support ( $p$-value $=0,007)$, information media $(p$-value $=0,011)$ with intention to stop smoking. This finding shows that the most influencing factor on intention to quit smoking is family support.
\end{abstract}

Keywords: Smoking Behavior, Smoking Cessation Inhibition, Intention To Stop Smoking, Smoking Cessation, Tobacco Control 


\section{INTRODUCTION}

Cigarette smoking has become a usual part of tobacco use in Indonesia. There is around onethird of Indonesia's population smokes. This large proportion of smokers, making Indonesia the thirdlargest tobacco consumer in the world after India and China (Hart and WHO in Tahlil et al., 2013). Based on WHO (2017), these are also considered as countries with a high proportion of smokers, including Serbia with a percentage of $41 \%$ or 3.3 million smokers, Bulgaria with a percentage of $35 \%$ or 2.2 million smokers, Russia $38 \%$ or 46.9 million smokers.

According to Basic Health Research Data (2013), the proportion of national smoking increased from $23.7 \%$ in 2007 to $29.3 \%$ in 2013 with the proportion of active smokers is $24.3 \%$, occasional smokers are 5.0\%, ex-smoker is $4 \%$ and a non-smoker is $66.6 \%$. The highest proportion of smokers is found in Kepulauan Riau with a percentage is $30.7 \%$ (Riskesdas,2013)

Meanwhile, Aceh is also one of the provinces with a high prevalence of smokers in Indonesia. The number of smokers in Aceh is almost similar to the national prevalence in that the proportion of smokers in Aceh province is $29.3 \%$ consisting of $25 \%$ active smokers, $4.3 \%$ occasional smokers, $2.5 \%$ ex-smokers, and $68.2 \%$ non-smokers. While, in Banda Aceh, the proportion of smokers was 27.3\%, 2.9\% of former smokers, and 69.8\% non-smokers in 2013(Dinas Kesehatan Aceh, 2013.

Smoking causes numerous health problems as many types of diseases were developed due to smoking behavior, either directly or indirectly. Furthermore, smoking habits are not only detrimental to smokers but also to those around them (Tendra, 2013). The Center for Tobacco Studies (CTCS) estimates that adolescent who starts early smoking, will be as a smoker for up to 10 years and resulted in difficulty to quit (CTCS, 2013).

A continuously increasing number of smokers in Aceh is influenced by a consideration of those smoking behaviors as part of tradition. This tradition of smoking was seen as a normative behavioral habit (Nitcher, 2009). Thus, cigarettes are one of the contributors to poverty in Aceh. Adan (2016) $70 \%$ of smokers are known to be lower to middle-class citizens, and that $15 \%$ of smokers' income is used to buy cigarettes (Adan, 2016).

A preliminary study conducted at Rumah Sakit Umum Daerah Zainoel Abidin (RSUDZA) in Banda Aceh found that the number of outpatient visits in Pulmonary Clinic in 2016 was 7,736 and January-September 2017 was 3,226 (RSUDZA, 2017). About 20\% who seek treatment at the Pulmonary Polyclinic of RSUDZA are diagnosed with diseases related to cigarette smoking including bronchitis due to smoking. The majority of patients were suffering from relapse bronchitis that indicating that they fail to quit smoking. The majority of patients or around $70 \%$ of them said that if they don't smoke, they have difficulty focusing and concentrate, experiencing restlessness, and become fat or increasing body weight. Whereas, if they smoke, they felt contrary and even felt more mature and can come up with ideas. These reasons expressed by patients showed 
psychological and physiological factors that influence smoking habits, and causing difficulty to quit smoking (Muntiarini S, 2011). Therefore, this finding makes researchers interested to research the intention to quit smoking among outpatients at the Pulmonary Clinic of RSUDZA in Banda Aceh.

Cigarettes are packaged tobacco products, which are addictive substances that are harmful to an individual's health. Other ingredients of cigarettes are produced from plants such as Nicotiana Tabacum, Nicotiana Rustica, and other species with or without additives (Tendra, 2003). Cigarettes may also be packed in cylinders of paper measuring around 70 to $120 \mathrm{~mm}$ long (varies by country) with a diameter of about $10 \mathrm{~mm}$ containing finely shredded tobacco leaves (Kalemben, 2016).

Cigarettes are made from tobacco that can be chewed and inhaled. Nicotine and cigarette smoke will be released from tobacco in the smoking process. Nicotine is bound to organic acids and remains bound to acids when the leaves are dried slowly. The content of the constituent compounds of cigarettes that can affect the user is alkaloids with their main effect as stimulants, including nicotine, nicotine, anabasine, myosin, and others. Nicotine is the compound that is most commonly found in cigarettes so that all alkaloids are considered as part of nicotine (Tendra, 2003).

Smokers had twice to four times risk of suffering from coronary heart disease, in addition to other preventable non-communicable diseases (Winurini S, 2016). These findings conclude with a claim that cigarette use may kill one person every ten seconds (WHO, 2002 in Tobuto et al., 2014), the cause of death of one in two smokers is related to cigarette consumption (Global Smoke-Free Partnership, 2009). Cigarette consumption in Indonesia has been in an alarming situation, it can be seen from multiple perspectives that smoking is negative behavior. Since the health impact of cigarettes is not abruptly happening, in other words, the consequences are non-acute. Cigarette smoke contributed to various chronic diseases, no one will suddenly die from smoking. The impact of cigarettes may be seen within 10-20 years after continuous exposure to cigarette smoke, such as it can increase the risk of heart and lung disease by 20-30\%. In addition, cigarette smoke may worsen the condition of an individual suffering from asthma, causing bronchitis and pneumonia (Sitepoe,2000).

There might many reasons for an individual to quit smoking and, while it is considered as the most important factor, but it is not merely about the strong will of smokers to quit. Interestingly, quit smoking may also be triggered by group or community decisions. Research from Harvard University and the University of California San Diego published in The New England Journal of Medicine in May 2008, research with the subjects are smokers and nonsmokers in the US, the study subject was followed for years of observation for 32 years, from 1971 to 2003. Consideration on quitting was analyzed whether influenced by the surrounding community, such as family, neighbors, coworkers, and friends. The results showed that smokers will stop smoking if their 
friends, family, neighbors stop smoking. That shows the decision to quit smoking is not a personal decision, but rather a group decision (Nubairi, 2015).

These are some of the reasons for the difficulty of quit smoking. First, cigarettes are legal products, so smokers feel they are not breaking the rules. While illicit drug users tend to hides while using drugs due to illegality and fear of against the law. Second, cigarettes are available and easy to buy anywhere, also with their affordable prices. Third, smokers are aware that they are not alone, there are many smokers around. And last, smokers might be unaware of the addiction they had experienced since cigarette addiction can be postponed. That is, even if the mouth tastes sour, headaches, or signs of addiction appear, a smoker can delay smoking. (Fathurrahman in Rosita et al., 2012). This study aims to determine the factors that inhibit quit smoking in out-patients smokers visiting Pulmonary Clinic of RSUDZA in Banda Aceh.

\section{METHODS}

This study uses quantitative methods with a cross-sectional design. The population in this study were all out-patients who visit the Pulmonary Clinic of RSUDZA in Banda Aceh who are active smokers. The research sample was 65 respondents who were selected by using the incremental sampling method. The data analyzed STATA version 13 with a chi-square statistical test.

\section{RESULTS AND DISCUSSION}

The Association between Duration of Smoking and Inhibition of Intention to Quit Smoking Based on the results, patients who smoked less than 5 years, consist of $3(27.27 \%)$ patients who had the intention to quit smoking and $8(72.73 \%)$ patients who had no intention to quit smoking. Meanwhile, patients who smoke more than 5 years, consisting of $34(62.96 \%)$ patients had the intention to quit smoking, and 20 (37.04\%) patients had no intention to quit smoking. The results of statistical tests showed that there was a relationship between the length of smoking and the Inhibition of Intention to quit smoking (P-value=0.029).

One of the addictive substances that makes it difficult to quit smoking is nicotine. The longer nicotine stays in the body, the stronger need to smoking, and causing difficulty to quit cigarette smoking. When an individual trying to quit smoking, reduced levels of nicotine in the body result in symptoms called "nicotine withdrawal symptoms," that affecting both physically and mentally (Darojah, 2014). Physiological needs lead to dependency causing smokers unable to quit and mentally feeling depressed and anxious when the urge to quit smoking (Sztompka, 2007).

The Relationship between Cigarettes Availability and Inhibition of Intention to Quit Smoking Based on the research conducted by patients with adequate availability of cigarettes, 23 (48.94\%) patients had the intention to quit smoking and $24(51.06 \%)$ patients had no intention to 
quit smoking. Meanwhile, patients with a lack of cigarette availability consisted of $14(77.78 \%)$ patients had the intention to quit smoking, and 4 (22.22\%) patients had no intention to quit smoking. The results of statistical tests showed that there was a significant relationship between the availability of cigarettes and the Inhibition of Intention to quit smoking (P-value=0.036).

One of the factors that inhibit intention to quit smoking is the availability of cigarettes, as well as the ability of smokers to purchase cigarettes. In addition, cigarette prices are relatively cheap and easy to reach because they can be purchased anytime and anywhere. Smokers may get cigarettes even easier, a research found that some teenagers even could get free cigarettes from friends or family (Artana, 2010).

The results of the study showed that the proportion of patients who had an influence from their social environment on the desire to quit smoking consisted of $21(45.65 \%)$ patients wanting to quit and $25(54.35 \%)$ patients not wanting to quit smoking. While the patients did not have the influence of the social environment, consisting of $16(84.21 \%)$ patients wanting to quit and 3 (15.79\%) patients not wanting to stop smoking. The statistical test showed that there was a significant relationship with the p-value of 0.004 .

This research is in line with Kumboyono's research (2012) where $69 \%$ of respondents know cigarettes from their friends. Mu'tadin (2002) also stated that smoking behavior occurs because it is influenced by friends. This is reinforced in the statement of Safitri (2010) that one of the influences of peers is in the formation of smoking habits.

The results showed that the proportion of patients who had family support for wanting to quit smoking consisted of $23(74.19 \%)$ patients wanting to quit and $8(25.81 \%)$ patients not wanting to quit. While patients do not have family support for wanting to quit smoking, consisting of 14 (41.18\%) patients wanting to quit and $20(58.82 \%)$ patients not wanting to quit. Statistical results show that there is a significant relationship with a p-value of 0.007 .

This research is supported by the research of Wahyuni, D and Sudaryanto, A (2010) with the title "factors related to a smoking attitude in adolescents in Karang Tengah village, Sragen subdistrict" with the result that parental factors influence smoking attitudes.

Based on the study, the proportion of patients who had family support for wanting to quit smoking, consisted of 23 (74.19\%) patients wanting to quit and 8 (25.81\%) patients not wanting to quit smoking. While the patients did not have family support, consisting of 14 (41.18\%) patients wanting to quit and $20(58.82 \%)$ patients not wanting to quit smoking. Statistical results show that there is a significant relationship with a p-value of 0.011 .

The results of the study are supported by Lizza M. Djapri (2011), the increasing tendency to smoke, especially teenagers, cannot be separated from the mass media. Cigarette advertisements are 
good at ensnaring consumers. The positive thing inserted to instill the perception of smoking is misleading.

The results of the study carried out that the factor with the greatest influence was family support. Statistical test results obtained p-value 0.002 and $\mathrm{OR}$ value $=36.47$, meaning that behavior that gets family support has 36 times the chance of wanting to quit smoking compared to behavior that does not get family support.

Families play a role in shaping children's attitudes. Family schools and places of learning. Parents are role models for their children, deep interactions between parents and children produce similar characters. Research (Iqbal, 2008) states that adolescents who smoke have parents who also smoke, and those aged $<13$ years are more susceptible to smoking than those aged $>13$ years.

Table 1. Univariate Variable

\begin{tabular}{|c|c|c|c|}
\hline Variable & & Frequency & Percent (\%) \\
\hline & Want to Quit Smoking & 37 & 56.92 \\
\hline Desire to Quit Smoking & $\begin{array}{l}\text { Don't Want To Quit } \\
\text { Smoking }\end{array}$ & 28 & 43.08 \\
\hline \multirow{2}{*}{ Smoking Time } & $<5$ Years & 11 & 16.92 \\
\hline & $\geq 5$ Years & 54 & 83.08 \\
\hline \multirow{3}{*}{ Availability of Cigarettes } & Easy & 47 & 72.31 \\
\hline & Difficult & 18 & 27.69 \\
\hline & Well & 28 & 43.08 \\
\hline Knowledge & Not enough & 37 & 56.92 \\
\hline \multirow{3}{*}{ Attitude } & Positive & 21 & 32.31 \\
\hline & Negative & 44 & 67.69 \\
\hline & Heavy & 40 & 61.54 \\
\hline Cigarette Addiction & Light & 25 & 38.46 \\
\hline \multirow{3}{*}{ Environmental Influence } & Take effect & 46 & 70.77 \\
\hline & No effect & 19 & 29.23 \\
\hline & Support & 31 & 47.69 \\
\hline Family support & Does not support & 34 & 52.31 \\
\hline \multirow{2}{*}{$\begin{array}{l}\text { Influence of Information } \\
\text { Media }\end{array}$} & Enough & 35 & 53.85 \\
\hline & Not enough & 30 & 46.15 \\
\hline
\end{tabular}

Table 2. Bivariate Variable

\begin{tabular}{|c|c|c|c|c|c|c|c|c|}
\hline \multirow{3}{*}{ Variable } & & \multicolumn{4}{|c|}{ Desire to Quit Smoking } & & & \multirow{3}{*}{$p$-value } \\
\hline & & \multicolumn{2}{|c|}{$\begin{array}{c}\text { Want to Quit } \\
\text { Smoking }\end{array}$} & \multicolumn{2}{|c|}{$\begin{array}{l}\text { Don't Want To } \\
\text { Quit Smoking }\end{array}$} & \multicolumn{2}{|c|}{ Total } & \\
\hline & & $\mathbf{n}$ & $\%$ & $\mathbf{n}$ & $\%$ & $\mathbf{n}$ & $\%$ & \\
\hline Smoking & $<5$ Years & 3 & 27.27 & 8 & 72.73 & 11 & 100 & \\
\hline Time & $\geq 5$ Years & 34 & 62.96 & 20 & 37.04 & 54 & 100 & 0.029 \\
\hline Availability of & Easy & 23 & 48.94 & 24 & 51.06 & 47 & 100 & \\
\hline Cigarettes & Difficult & 14 & 77.78 & 4 & 22.22 & 18 & 100 & 0.036 \\
\hline
\end{tabular}




\begin{tabular}{|c|c|c|c|c|c|c|c|c|}
\hline \multirow{3}{*}{ Variable } & & \multicolumn{4}{|c|}{ Desire to Quit Smoking } & & & \multirow{3}{*}{$p$-value } \\
\hline & & \multicolumn{2}{|c|}{$\begin{array}{l}\text { Want to Quit } \\
\text { Smoking }\end{array}$} & \multicolumn{2}{|c|}{$\begin{array}{l}\text { Don't Want To } \\
\text { Quit Smoking }\end{array}$} & \multicolumn{2}{|c|}{ Total } & \\
\hline & & $\mathbf{n}$ & $\%$ & $\mathbf{n}$ & $\%$ & $\mathbf{n}$ & $\%$ & \\
\hline \multirow{4}{*}{ Knowledge } & Well & 21 & 75 & 7 & 25 & 28 & 100 & \multirow{3}{*}{0.01} \\
\hline & Not & & & & & & & \\
\hline & enough & 16 & 43.24 & 21 & 56.76 & 37 & 100 & \\
\hline & Positive & 16 & 76.19 & 5 & 23.81 & 21 & 100 & \multirow{3}{*}{0.03} \\
\hline \multirow{3}{*}{$\begin{array}{l}\text { Attitude } \\
\text { Cigarette } \\
\text { Addiction }\end{array}$} & Negative & 21 & 47.73 & 23 & 52.27 & 44 & 100 & \\
\hline & Heavy & 29 & 72.5 & 11 & 27.5 & 40 & 100 & \\
\hline & Light & 8 & 32 & 17 & 68 & 25 & 100 & 0.001 \\
\hline \multirow{2}{*}{$\begin{array}{l}\text { Environmental } \\
\text { Influence }\end{array}$} & $\begin{array}{l}\text { Take } \\
\text { effect }\end{array}$ & 21 & 45.65 & 25 & 54.35 & 46 & 100 & \multirow[t]{2}{*}{0.004} \\
\hline & No effect & 16 & 84.21 & 3 & 15.79 & 19 & 100 & \\
\hline \multirow{4}{*}{$\begin{array}{l}\text { Family } \\
\text { support }\end{array}$} & Support & 23 & 74.19 & 8 & 25.81 & 31 & 100 & \multirow{3}{*}{0.007} \\
\hline & Less & & & & & & & \\
\hline & Support & 14 & 41.18 & 20 & 58.82 & 34 & 100 & \\
\hline & Enough & 25 & 71.43 & 10 & 28.57 & 35 & 100 & \multirow{3}{*}{0.011} \\
\hline \multirow{2}{*}{$\begin{array}{l}\text { Information } \\
\text { Media }\end{array}$} & Not & & & & & & & \\
\hline & enough & 12 & 40 & 18 & 60 & 30 & 100 & \\
\hline
\end{tabular}

\section{CONCLUSIONS AND SUGGESTIONS}

Factors inhibiting the desire to stop smoking patients seeking treatment at the Pulmonary Polyclinic RSUD dr. Zainoel Abidin Banda Aceh has a significant relationship between the dependent and independent variables. The factor of smoking duration p-value 0.029. Availability of cigarettes p-value 0.036. Knowledge of p-value 0.01. Attitude p-value 0.03. Addiction value p-value 0.001. Environmental p-value value 0.004. Family support p-value 0.007. Media information value p-value 0.011. The biggest influence factor is family support. p-value 0.002 and $\mathrm{OR}=36.47$, meaning that family support has 36 times the chance of wanting to quit smoking compared to the behavior of not getting family support.

Hospitals can take advantage of smoking counseling and socialization programs in pulmonary polyclinics. Respondents are expected to use counseling facilities to stop smoking. The government needs a media campaign to stop smoking and increase the area (KTR). The next researcher conducts in-depth research with a long time and a more representative number of samples. The public pays attention and provides information on the impact of losses due to smoking.

\section{REFERENCES}

1. Tahlil T., Coveney J., Woodman R.J. \& Ward P.R., Exploring recommendations for an effective smoking prevention program for Indonesian adolescents, Asian Pacific Journal of Cancer Prevention, 2013;14(2):865-871.

2. Riskesdas., Basic Health Research. Jakarta: 2013.

3. Aceh Health Office., Aceh Provincial Health Office Profile. Banda Aceh: 2013. 
4. Tendra H., Tobacco and Its Products, Jakarta: Rineka Cipta, 2003.

5. 5. CTCS C.F.T.C.S., Generation of Aceh Without Smoking, http://ctcs.acehreasearch.org, 2013.

6. Nitcher., Factors Affecting the High Number of Smokers Among Students, Thesis.

7. Faculty of Public Health. University of Indonesia. 2009.

8. Adan H.Y., Generation of Coffee Shops, http://aceh.tribunnews.com/, 2016.

9. RSUDZA., Regional General Hospital report dr. Zainoel Abidin Banda Aceh. Banda 10.Aceh. 2017.

11.Muntiarini S., Relationship between Social Support and Motivation to Quit Smoking in Young Men at MAN Blitar City, Thesis of the Department of Guidance and Counseling \& Psychology-Faculty of Education UM, 2011.

12.Kalemben S., Smoking Behavior in Students at Hasanuddin University Makassar City in 2016. Makassar; 2016.

13.Winurini S., Causes of Relapse (return to smoking) in Heavy Smokers in terms of 14. Health Belief Model, Journal of Aspiration (Trial), 2016; 2(1):31-46.

15.Sitepoe., Specialty of Indonesian Cigarettes, Jakarta: PT Grasindo; 2000.

16.Nubairi A.R., Qualitative Analysis of Factors Affecting Difficulty of Students of 17. Syarif Hidayatullah State Islamic University Jakarta Quitting Smoking, 2015.

18.Rosita R., Suswardany D.L. \& Abidin Z., Determinants of successful smoking cessation in college students, Journal of Public Health, 2012; 8(1):1-9.

19.Darojah S., Determinant Factors Inhibiting Smoking Cessation in Heads of Families in Jatiyoso

District, Karanganyar Regency: University of Muhammadiyah Surakarta;

20.2014 .

21.Sztompka P., Sociology of Social Change, Jakarta: Prenada, 2007.

22.Artana Putra., Effect of Cigarettes and the Impact of Dangers of Smoking on Health.

23.Bandung: PT Sarana Panca Karya Nusa. 2010.

24.Notoatmodjo S., Health Research Methodology. Jakarta: Rineka Cipta. 2012.

25.Kumboyono. The Relationship between Smoking Behavior and Learning Motivation for Adolescents at SMK Bina Bangsa Malang. Malang : Universitas Brawijaya; 2012.

26.Mu'tadin, Z., Independence as a Psychological Need in Adolescents. 2002. (Online).

27.Available:https://www.epsikologi.com/remaja.050602.html

28. Wahyuni, D \& Sudaryanto, A., Factors related to smoking attitude among adolescents in Karang Tengah village, Sragen sub-district. Thesis. Faculty of Health Sciences. Muhammadiyah University of Surakarta. Surakarta; 2010. 
29.Iqbal, M.F. Smoking behavior of adolescents in RW 22 Sukatani Village, Cimanggis District in 2008. Journal of the Public Health Undergraduate Program, Faculty of Public Health. Depok: University of Indonesia; 2008. 
Volume I Tahun 2021

November 2021
E-ISSN: 2808-5361

http://e-journal.fkmumj.ac.id/
Proceeding The First Muhammadiyah InternasionalPublic Health and Medicine Conference 